\title{
Preliminary Exploration on the Innovation of Teaching Management Mode in Local Colleges and Universities
}

\author{
Shuxia Qian \\ Jilin Agricultural University \\ Jilin, China
}

\author{
Xiaoming Zhang \\ Jilin Agricultural University \\ Jilin, China
}

\begin{abstract}
With the development of our country's society and economy and increasing demands for innovative talents, higher education has been forced into a new era of innovation. The existing teaching management mode cannot meet the needs of the current university management. The reform and innovation of teaching management mode in colleges and universities have become inevitable. On the basis of analyzing the necessity and the existing problems of the innovation of the teaching management mode in colleges and universities, the article puts forward the measures of the innovation of teaching management mode in local colleges and universities.
\end{abstract}

Keywords-local colleges and universities; teaching management mode; innovation measures

\section{INTRODUCTION}

Teaching management is an important part of the management of colleges and universities, and it is the prerequisite and foundation of the university management. With the advance of time, the reform and innovation of the teaching management mode in our country has made certain achievements. However, due to the fact that China's higher education is in the transitional period, the teaching management is facing new opportunities and challenges, and some new problems inevitably arise in the process of the reform and innovation of the teaching management mode in our country. For this reason, teaching administrators in colleges and universities are required to change their ideas and innovate on teaching management model to realize a high degree of unity of the university teaching management mode and personnel training mode, so as to achieve the purpose of improving the quality of personnel training.

\section{THE NECESSITY OF THE INNOVATION OF TEACHING MANAGEMENT MODE IN COLlEGES AND UNIVERSITIES}

\section{A. Innovation of the Teaching Management Mode of Colleges} and Universities Is the Need of Colleges and Universities to Adapt to the New International Situation

From the international perspective, with the deepening of economic globalization and the continuous opening up of higher education, higher education in the world is confronted with opportunities and challenges. In the face of the opportunities and challenges, to be invincible in the international competition, our colleges and universities must continue to strengthen the teaching management mode to achieve standardization and rationalization of teaching management. At the same time, the key to the current international competition lies in talent competition. In order to further improve the international competitiveness of our country, we must rely on higher education to provide talent resources and talent training in colleges and universities need to rely on sound teaching management to achieve[1].

\section{B. Innovation of Teaching Management Mode Is Inevitable in the New Era}

In recent years, reform of China's higher education management system has made a series of significant achievements. Internal management, especially the problem of teaching management has gradually become the core content of the work of colleges and universities and teaching management has become the top priority of the development of colleges and universities. Therefore, the teaching management mode in colleges and universities must adapt to the new situation of development of modern education with the replacement of traditional concept by concept of modern education and management to build a set of advanced, scientific, efficient and harmonious modern teaching management system.

\section{Innovation of the Teaching Management Mode Is the Inevitable Trend of Development of Modernized Teaching \\ With the advent of the information age and the transformation from the external development to the connotation development of colleges and universities, the reform and the innovation of teaching is increasingly deepening, the teaching management task is increasing day by day, the requirements of modernization and informatization level of teaching management are getting higher and higher. Therefore, it is urgent for colleges and universities to innovate on the teaching management mode and improve the methods of modern teaching management so as to achieve the goal of development of modernized teaching.}


III. The Existing Problems of Teaching Management IN COLLEGES AND UNIVERSITIES

\section{A. The Implementation of "People-Oriented" Concept of Teaching Management Does Not Reach the Designated Position}

With the deepening of the reform of higher education, "people-oriented" concept of teaching management has been gradually formed and implemented in all aspects of teaching management, but in the actual operation process of teaching management there are still many problems. First, poor communication channels with students and too much emphasis on requirements of teaching management system cannot really reflect the students' dominant position. Second, the lack of autonomy of teaching activities and flexibility of teaching arrangements hinder the development of students' personality and affect the enthusiasm and initiative of students for learning. Third, the lack of a sound guidance mechanism of course selection system leads to blind election of the majority of students. Fourth, the lack of democracy and humanity, teachers and students are in a passive and obedient position which is difficult to have the right to speak. Fifth, there are few teachers and students have ways and opportunities to participate in school decision-making and planning which results in the lack of a sense of belonging for teachers and cannot stimulate the enthusiasm and initiative of teachers for teaching and research .

\section{B. Insufficient Decentralization of Management Authority and Rough Secondary Management}

With the transformation from the traditional centralized management system to the secondary management mode of university and school, the focus of university management shifted from "university" to "school", which fully mobilized the enthusiasm of school-level management and injected new vitality into higher education activities. But in the implementation process of secondary management mode of university and school there are still many problems: First, it lacks scientific management objectives system. Secondary management is only an extension of university management and there is no management objective of itself. Second, it is not enough for decentralization of management authority. Many colleges and universities dare not move management center down to the school, resulting in tasks for colleges and universities are more cumbersome. Third, the decentralization of right and interest is not enough resulting in secondary schools taking obligations without right which combats the enthusiasm of the school work. Fourth, it is not enough for the implementation of management system. The actual implementation of secondary school management system policy in practice is not enough, resulting in poor management. Fifth, the overall quality of management is low. Managers do not have professional management skills and experience with low management efficiency and quality because of little attention to the staff of secondary school management[2].

\section{Imperfect Quality Evaluation and Incentive Mechanism}

In recent years, with the development of higher education, colleges and universities transform from quantity development to quality development. Colleges and universities continue to strengthen the awareness of teaching quality and develop a series of quality monitoring and evaluation mechanisms to upgrade the teaching quality. But there are still many problems, such as the formalization of teaching monitoring system, more qualitative evaluation and less quantitative evaluation, evaluation results are not implemented and so on. Colleges and universities lack scientific and rational evaluation system and perfect matching mechanism for feedback on evaluation. The information collection is often partial. In the evaluation, qualitative methods are more than quantitative analysis, simple evaluation is more than comprehensive evaluation and the overall evaluation is even less. The results are not implemented in the designated position, the assessment is largely a mere formality and the evaluation of teaching management is too superficial. Teachers' performance evaluation lacks effective standards and there is bias of emphasis on scientific research and teaching with the existing situation of paying more attention to scientific research and less to teaching.

\section{The Low Quality of Teaching Management Staff}

At present, most colleges and universities neglect the whole construction of teaching management team and cannot objectively evaluate the status, role and work intensity of teaching management personnel because they think that any person can serve as this role, which results in frequent replacement, improper connection of work, making teaching management staff have a bad grasp of the laws of higher education and low level of management capacity. Many colleges and universities do not have perfect incentive policies for teaching management personnel about selection, training, employment and promotion. There is little exchange and learning opportunities for management personnel so that they cannot update the management philosophy with narrow horizons and poor ability of innovation. Teaching management staff generally has low educational background and mismatched profession, lack opportunities for learning, training and further study so that they cannot add new knowledge and skills in time with poor usage of modern management methods.

\section{E. Lag of Informatization for Teaching Management}

With the advent of the information age, the requirements of informatization level of higher education management are higher and higher. Therefore, colleges and universities adopt different measures and means to improve their informatization management level. But in practical work there are still many problems: First, there are some shortcomings and maladjustments in the set of teaching management system for teaching management informationization currently used by many colleges and universities, which even produces checks and balances for specific work, because the development and design of system software are mainly designed for the ubiquitous problems of teaching management in colleges and universities. Second, the development of informatization system of teaching management in colleges and universities is slow, leading to the lack of relative regulations for guarantee and restraint in the specific work. Mutual buck-passing because of unclear responsibilities when problems arise restricts the efficient operation of teaching management system. 
Third, in the daily teaching management activities, the majority of teaching managers is not graduated from the major of computer so they do not have the ability of computer application and operation required by the informatization of teaching management and cannot complete teaching management activities well.

\section{The Proposed Solution to THE Problem}

\section{A. Change Ideas and Strengthen the Importance of the Teaching Management}

In order to adapt to the development trend of higher education at present, colleges and universities should keep pace with the times, change their ideas and give full attention to the teaching management of schools. First of all, to change the management philosophy of leaders at all levels, colleges and universities should strengthen the importance of teaching management in the school work, emancipate the mind, forge ahead, innovate bravely and ensure the smooth development of teaching management; Second, colleges and universities should strengthen teachers' understanding of teaching management, actively cooperate with the teaching management department to carry out related work and ensure the stable operation of teaching management; Third, we must strengthen the understanding of students for teaching management, strengthen students' understanding of rules of classroom teaching, courses selection, assessment of teaching practices, and actively cooperate with the teaching management department for teaching management to lay an important prerequisite for the stable and healthy development of colleges and universities[3].

\section{B. Innovate Ideas and Make the Dominant Position of Teachers and Students Definite}

In the course of teaching management, the teaching management personnel in colleges and universities should make the principal position of teachers and students definite, and truly embody the concept of "people-oriented" teaching management. Under the prerequisite of ensuring the normal operation of teaching activities, we should give full consideration to students' interests, respect students' concerns, thinking problems on the students' point of view, safeguard the students' legitimate rights and provide equal opportunities and resources, pay attention to the process management of students, monitor school roll of students at any time and deal with problems of academic aspects, pay attention to stimulate and attract teachers and students participating in teaching management, establish mechanism of operating management supervised and controlled by teachers, students and teaching management departments, transform administration to guidance and services, give teachers and students full right to speak and give full play role of feedback on the evaluation of teaching management by teachers and students to promote good and efficient operation of teaching management.

\section{Decentralize Power Reasonably ad Improve the Department's Management Authority}

Colleges and universities should reform the system of traditional centralization and administrative command, change the function of headmaster or vice president in charge of teaching and the office of teaching affairs, strengthen their macroscopic planning and guiding function, decentralize part of management power to the faculty, enhance the openness of decision-making and the diversification of program content, the flexibility of program execution and the scientific nature of evaluation and analysis. Colleges and universities should allow them to creatively carry out teaching management work in practice and genuinely delegate most of the management rights of people, finance and property to the secondary schools[4].

\section{Stress Feedback and Improve the Quality of Teaching Monitoring System}

To improve the monitoring system of teaching quality is the key to improve the quality of teaching management and is a necessary condition to improve the overall level of the school running. Practice has proved that the establishment of a sound, effective and comprehensive teaching quality monitoring system is important for the improvement of teaching quality and quality of personnel training. In the teaching process, we should to make whole process of monitoring and network monitoring well, make good reflecting chain of information based on teaching supervisor and student information officer, identify problems and solve problems in time, pay attention to multi-form monitoring, such as exam monitoring, assessment monitoring, regulation monitoring and so on.

\section{E. Pay Attention to Science and Introduce Modern Management Methods and Technologies}

Modern managers must be open-minded, adapt to the development and requirements of the situation, introduce modern scientific theory and management methods such as systematic and scientific cybernetics, information theory in the teaching management. At the same time, we must make full use of network means, be good at drawing on foreign successful experience, establish sound decision-making mechanism about information management system, decisionmaking system, monitoring system, enhance scientific and normative decision-making and management, reduce blindness and empiricism, improve the awareness of informatization of teaching management, complete the informatization system of teaching management, perfect the informatization institution of teaching management, optimize the quality of teaching management personnel[5].

\section{F. Strengthen Management and Constantly Improve the Quality of Teaching Managers}

To strengthen the construction of the teaching management team and improve the overall quality, we must first actively create conditions for the training of the teaching management personnel. Through training and on-the-job training we can enrich their own management knowledge about teaching management, fully tap the creativity of teaching management personnel, improve the ability to analyze and solve problems of teaching management staff by modern management knowledge and improve their organizational and leadership skills. Second, we must change our minds, correct service attitude, clarify the duties of teaching management staff to improve the sense of service for teachers and students. Third, 
to standardize employment mechanism of the teaching management personnel, we should employ teaching management personnel in strict accordance with the quality requirements, make relevant incentive policies about the assessment and promotion of teaching management staff to ease the management work.

\section{CONCLUSION}

In recent years, higher education has changed from "extension type" to "connotation type". Higher education has entered the era of innovation education, and innovation education requires innovation management. To this end, colleges and universities should combine the latest characteristics of economic development, create a new model of higher education management to achieve teaching management innovation, and continuously improve the overall quality and level of teaching management in colleges and universities to achieve efficient and high-quality operation of the teaching management in colleges and universities.

\section{REFERENCES}

[1] Yin Chun-yan, thinking on the innovation of teaching management mode in colleges and universities [J] Chifeng College Journal (Natural Science Edition) 2014 (7): 157-159

[2] Du Jingjing, research and study on teaching management mode of secondary school in university[J], Literature Education, 2013 (9): 62

[3] Li Zhengyi, exploration of teaching management mode in universities under the concept of "student-oriented" [J], Journal of Tonghua Normal University (Humanities and Social Sciences), 2013 (7): 138-140

[4] Liu Ting, innovation and practical discussion of teaching management in universities [J] Modern Enterprise Education 2014 (20): 208

[5] Ye Xiaoqin, exploration and practice of informatization construction of teaching management [J], Teaching and Management, 2013 (24): 28-30. 